\title{
Variation in spirometry parameters in children with and without recurrent respiratory problems
}

\section{Gauchan $\mathrm{E}^{1}$ (D), $\mathrm{BK} \mathrm{G}^{2}$ (D), Koirala DP ${ }^{3}$ iD}

${ }^{1}$ Eva Gauchan, Associate Professor; ${ }^{2}$ Ganesh BK, Lecturer; ${ }^{3}$ Deepak Prasad Koirala; Assistant Professor; Department of Pediatrics, Manipal College of Medical Sciences; Pokhara, Nepal.

\begin{abstract}
Background: Children having recurrent episodes of respiratory symptoms account for a major source of hospitalization. These children have increased morbidities and if not identified in time can have impaired lung function as adults.

Objectives: The aim of our study was to compare the spirometry parameters and bronchodilator reversibility in children with and without recurrent respiratory problems.

Methods: This was a prospective observational study conducted in the Pediatric department of Manipal Teaching Hospital comparing 35 children with recurrent respiratory problems and 35 children with no history of recurrent respiratory problems. After thorough instructions, baseline spirometry was done in all children and recordings were noted. Thereafter they were given two puffs of salbutamol $(100 \mu \mathrm{g})$ and repeat testing was done 20 minutes later. Bronchodilator reversibility was calculated according to standard formula. Various statistical tests were used to compare the findings between the two groups.

Results: The recurrent respiratory problem group had 31 (88\%) cases of bronchial asthma, two (5.7\%) bronchiolitis obliterans, one (2.8\%) pulmonary eosinophilia, and one (2.8\%) common variable immunodeficiency syndrome. The median values of $\mathrm{FEV}_{1}(\mathrm{p}=<0.001), \mathrm{FVC}(\mathrm{p}=0.007), \mathrm{FEV}_{1} / \mathrm{FVC}(\mathrm{p}=0.005), \operatorname{PEF}(\mathrm{p}=0.042)$ and $\mathrm{FEF}_{25-75}(\mathrm{p}=0.026)$ were lower in the group with recurrent respiratory problems. Post-bronchodilator reversibility of $F E V_{1}(p=0.001), F V C(p=<0.001)$ and $\mathrm{FEF}_{25-75}(\mathrm{p}=0.026)$ was higher in the groups with recurrent respiratory problems

Conclusion: Lung function parameters in children with recurrent respiratory problems showed features of obstructive defect. The post-bronchodilator response was higher in the group with recurrent respiratory problems as compared to normal children.
\end{abstract}

Key words: Child; Recurrent; Respiratory problem; Spirometry.

Access this article online

Website: www.jkmc.com.np

DOI: https://doi.org/10.3126/jkmc.v9i3.36413

HOW TO CITE

Gauchan E, BK G, Koirala DP. Variation in spirometry parameters in children with and without recurrent respiratory problems. J Kathmandu Med Coll. 2020;9(3):130-6.

Address for correspondence

Dr. Eva Gauchan

Associate Professor and Head of Department

Department of Pediatrics

Manipal College of Medical Sciences

Pokhara, Neapl

E-mail: evagauchan@gmail.com

Copyright $\odot 2020$ Journal of Kathmandu Medical College (JKMC)

ISSN: 2019-1785 (Print), 2091-1793 (Online) Attribution-Non Commercial 4.0 International License.

\section{INTRODUCTION}

espiratory symptoms account for one of the most - common causes of hospital visits in children $<15$ years of age. Recurrent respiratory symptoms in children can be manifested as repeated episodes of cough, audible wheezing, stridor, respiratory tract infections, etc. Among the many causes of recurrent respiratory symptoms are aspiration syndromes, bronchial asthma, immunodeficiency syndromes, congenital heart disease, foreign body aspiration, anomalies of the respiratory system, gastroesophageal reflux, etc ${ }^{1-3}$. Children with repeated episodes of respiratory symptoms have higher morbidities like failure to thrive, psychological distress due to repeated illness and the trauma that repeated hospitalization causes; not to mention the financial burden it poses to the family.

Spirometry is a tool that is used to measure lung volumes during forced breathing maneuvers. Lung function parameters are influenced by many factors like age, sex, 
ethnicity, weight, height, environmental factors, method and patient effort, presence or absence of respiratory diseases,etc ${ }^{4-6}$. Reference ranges have been devised in several populations to define normality due to these various factors ${ }^{7-11}$. This test has traditionally been used to diagnose obstructive airway diseases like bronchial asthma, but it has been found to be abnormal in many other diseases as well ,, $12-18$. Spirometry is not difficult to do but it is not a test that is widely used in children ${ }^{19,20}$. One of the reasons why it is not so much in use is because children are not able to perform the forced voluntary breathing that is required for this test. However, newer techniques introduced have made it possible to measure lung function in children as young as 24 months of age $^{21}$. No studies were found which tried to analyze the difference in spirometry findings in children with and without recurrent respiratory problems in our part of the world. So the primary aim of our study was to find if differences exist in spirometry parameters in children with and without recurrent respiratory problems. The secondary aim was to find the postbronchodilator response between the two groups.

\section{METHODS}

This was a prospective, observational study conducted at Manipal Teaching Hospital over a duration of one year. Children between the ages of 6-13 years brought to the pediatric department for recurrent respiratory symptoms were recruited for the study. A modified American Thoracic Society and Division of Lung Diseases (ATS-DLD-78-C) questionnaire ${ }^{22}$ was filled for all children to assess the presence of respiratory symptoms. To act as controls, children who were admitted for other illnesses and had no history of recurrent respiratory symptoms were enrolled. For the purpose of this study, recurrent respiratory symptom was defined as the presence of cough with shortness of breath or audible wheezing or fast breathing two or more times in a year or three or more episodes ever. Excluded were children less than six years of age with recurrent respiratory symptoms, children unable to follow instructions to perform the procedure, those on long-term inhaler therapy, the presence of obvious structural deformity of the chest, and patients who did not give consent. This study was approved by the institutional review committee (IRC) prior to patient enrolment. Informed consent was taken from the patient's guardian/parents. The sample size was calculated using the means and standard deviation from a previously conducted study ${ }^{23}$. Demographic details were noted in a predesigned proforma. Anthropometric details especially weight and height were noted and body mass index (BMI) calculated using standard formula. In children with recurrent respiratory problems (RP) history, frequency, date of last attack, and diagnosis were noted. Diagnosis of children in the no-recurrent respiratory problems (nRP) group was also noted.

Before performing the pulmonary function test (spirometry), the procedure was properly explained to the subject. His/her understanding of the instruction was assessed by asking him to repeat the instructions. A technician trained in spirometry (breath-educator) explained and assisted the child to perform the test. We used Spirolab III ver 4.1 SN 311436 to perform the test. Spirometry was done in the sitting upright position with feet placed firmly on the ground. Three attempts were made and the highest of three readings was taken as the final value. The test was assessed for accuracy as well as repeatability and was considered successful if both the criteria were met based on the ATS-DLD criteria ${ }^{24}$. The child was asked to take a deep breath in followed by a forced exhalation on the mouth-piece. Then he was asked to take a deep breath in followed by an exhalation. The respiratory efforts were recorded on a graph paper which depicted flow-volume and volume-time curves. Various parameters recorded were forced expiratory volume in the first second ( $\left.\mathrm{FEV}_{1}\right)$, forced vital capacity $(F V C)$, ratio of $F E V_{1} / F V C$, peak expiratory flow (PEF), forced expiratory flow between $25 \%$ to $75 \%$ of forced vital capacity $\left(\mathrm{FEF}_{25-75}\right)$. The predicted normal value was automatically calculated by the spirometer based on the standing height. After obtaining these readings salbutamol two puffs of $100 \mu \mathrm{g}$ each were given from a metered-dose inhaler and the test was repeated 20 minutes later.

Bronchodilator reversibility was calculated by using the formula: Post-bronchodilator value- Prebronchodilator value/Pre-bronchodilator value x 100 .

Statistical analysis was done by SPSS ver 20. The normality of data was checked by the Shapiro-Wilk test. Bivariate analysis was done using Chi-square tests to compare the two groups for categorical data which were presented as absolute number (\%). Continuous data which were found to be non-normally distributed were expressed as median [interquartile range] while if normally distributed it was expressed as mean (SD). For analysis of continuous variables, the Mann-Whitney $U$ test or independent sample t-test was used as necessary. A p-value $<0.05$ was considered statistically significant.

\section{RESULTS}

A total of 70 children were enrolled in the study; of which 35 cases were in the recurrent RP group and 35 
cases in the no-recurrent RP group. The median age of presentation in years in the two groups was 10 [6-13] and 12 [8-13] respectively. Male: female ratio in the recurrent RP group was 1.91:1 while in no recurrent RP group it was 1.18:1. The recurrent RP group comprised of 31 (88\%) bronchial asthma, two (5.7\%) bronchiolitis obliterans, one $(2.8 \%)$ pulmonary eosinophilia, and one $(2.8 \%)$ common variable immunodeficiency syndrome while the no-recurrent RP group consisted of cases who visited the department for other non-respiratory illnesses. The demographic characteristics of the two groups are as shown in Table 1.

The spirometric evaluation showed that the median values of $\mathrm{FEV}_{1}$ were lower in the recurrent RP group as compared to the no-recurrent RP group. Similarly, FVC, $\mathrm{FEV}_{1} / \mathrm{FVC}, \mathrm{PEF}$, and $\mathrm{FEF}_{25-75}$ were all lower in the group with recurrent $\mathrm{RP}$ than in the no-recurrent RP group. The mean value of $\mathrm{FEV}_{1}, \mathrm{FVC}, \mathrm{FEV}_{1} / \mathrm{FVC}, \mathrm{PEF}$, and $\mathrm{FEF}_{25-75}$ in terms of percentage of predicted value was found to be lower in the recurrent RP group as compared to norecurrent RP group (Table 2 ).

Bronchodilator reversibility in the various spirometric parameters assessed after nebulization with salbutamol shows that there was a difference between the two

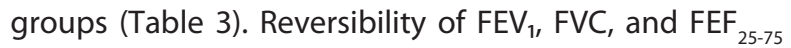
was significantly higher in the group with recurrent RP as compared to the no-recurrent RP group however there was no significant difference in the $\mathrm{FEV}_{1} / \mathrm{FVC}$.

Table 1: Characteristics of subjects with and without recurrent respiratory problems

\begin{tabular}{|c|c|c|}
\hline Characteristic & Recurrent RP ( $n=35)$ & No-recurrent RP $(n=35)$ \\
\hline Age in years ${ }^{*}$ & $10[6-13]$ & $12[8-13]$ \\
\hline Male gender ${ }^{* *}$ & $23(65.7 \%)$ & $19(54.3 \%)$ \\
\hline Resides near busy roads** & $14(40 \%)$ & $5(14.3 \%)$ \\
\hline Family members ${ }^{*}$ & $4[2-8]$ & $4[2-18]$ \\
\hline Number of rooms* & $3[1-9]$ & $3[2-11]$ \\
\hline Has in-house smoker in family ${ }^{* *}$ & $3(8.6 \%)$ & $8(22.9 \%)$ \\
\hline Uses firewood for cooking ${ }^{* *}$ & $1(2.9 \%)$ & $2(5.7 \%)$ \\
\hline Episodes of respiratory illness* & $3[2-12]$ & $0.00[0-1]$ \\
\hline Weight in $\mathrm{kgs}^{*}$ & $30[15-52]$ & $31[19-50]$ \\
\hline Height in $\mathrm{cm}^{*}$ & 139 [108-169] & 139 [116-165] \\
\hline $\mathrm{BMI}$ in kg/sq. $\mathrm{m}^{*}$ & $15.3[12.4-22]$ & 16 [12-21] \\
\hline
\end{tabular}

*median [IQR]; ** $\mathrm{n} \%$

Table 2: Baseline spirometric parameters of children with and without recurrent respiratory problems

\begin{tabular}{|c|c|c|c|}
\hline Parameter & Recurrent RP & No-recurrent RP & p-value \\
\hline $\mathrm{FEV}_{1}^{*}$ & $1.5[0.4-3.5]$ & $1.8[0.97-3.18]$ & $<0.001$ \\
\hline $\mathrm{FVC}^{*}$ & $1.6[0.47-4]$ & 2 [1-3.7] & 0.007 \\
\hline $\mathrm{FEV}_{1} / \mathrm{FVC}^{*}$ & 86.7 [64-100] & 89 [81-100] & 0.005 \\
\hline $\mathrm{PEF}^{*}$ & $2.4[0.6-6.6]$ & $2.8[2-6.2]$ & 0.042 \\
\hline $\mathrm{FEF}_{25-75}{ }^{*}$ & $1.38[0.54-4]$ & $2.3[1-4.3]$ & 0.026 \\
\hline \multicolumn{4}{|c|}{ Measure of $\%$ predicted } \\
\hline $\mathrm{FEV}_{1}{ }^{* *}$ & $75.7(22.7)$ & $102.5(27.6)$ & $<0.001$ \\
\hline $\mathrm{FVC}^{* *}$ & $79.5(19.6)$ & $101(25)$ & $<0.001$ \\
\hline $\mathrm{FEV}_{1} / \mathrm{FVC}^{* *}$ & $91.4(10)$ & $98(6)$ & 0.001 \\
\hline $\mathrm{PEF}^{* *}$ & $62.4(23.5)$ & $75.2(20.8)$ & 0.022 \\
\hline $\mathrm{FEF}_{25-75}{ }^{* *}$ & $62.7(29)$ & $92(31.7)$ & $<0.001$ \\
\hline
\end{tabular}

*median $[\mathrm{IQR}] ;{ }^{* *}$ means $( \pm \mathrm{SD})$ 
Table 3: Reversibility in selected parameters after nebulization with salbutamol in the groups with and without recurrent respiratory problems

\begin{tabular}{lccc|}
\hline Parameter & Recurrent RP & No-recurrent RP & p-value \\
\hline FEV $_{1} \%-$ PB $^{\text {R* }}$ & $11[-16,54]$ & $5.5[-35,19]$ & 0.001 \\
\hline FVC\%-PBR & $7[-16,33]$ & $4[-21,24]$ & $<0.001$ \\
\hline FEV $_{1} /$ FVC\%-PBR $^{*}$ & $-9[-28,21]$ & $0.00[-20,11]$ & 0.657 \\
FEF $_{25-75} \%-$ PBR $^{*}$ & $26[-42,173]$ & $14[-54,71]$ & 0.026 \\
\hline
\end{tabular}

*median [IQR]

\section{DISCUSSION}

We conducted this study to compare the spirometry parameters in children with and without recurrent respiratory problems. To the best of our knowledge, this is the first study of its kind conducted in our part of the world. Spirometry has been used in the management of children with bronchial asthma for some time now ${ }^{12,21,23,25,26}$. Several studies have shown that derangements in lung function parameters can also be seen in bronchiolitis obliterans, bronchiectasis (cystic fibrosis-associated or otherwise), hemoglobin disorders like sickle cell disease, etc ${ }^{14,15,18,27,28}$. In our study maximum cases were of bronchial asthma while two were of bronchiolitis obliterans. Both these conditions are characterized by variable airflow obstruction. While in bronchial asthma the obstruction is said to be reversible; in bronchiolitis obliterans, it is said to be only partially reversible. Our study found that the baseline spirometry parameters $\left(\mathrm{FEV}_{1}, \mathrm{FVC}, \mathrm{FEV}_{1} / \mathrm{FVC}\right.$, $\mathrm{PEF}$, and $\mathrm{FEF}_{25-75}$ ) were all significantly lower in the recurrent RP group as compared to the no-recurrent $\mathrm{RP}$ group. The mean values of percentage predicted of $\mathrm{FEV}_{1}, \mathrm{FVC}, \mathrm{PEF}$, and $\mathrm{FEF}_{25-75}$ were lower than the standard accepted level of $80 \%$ while the ratio of $\mathrm{FEV}_{1}$ / FVC was just above the acceptable level of $90 \%$ in the recurrent RP group as compared to the no-recurrent RP group where all the parameters were above the cutoff level. This indicates that there were varying degrees of obstruction in the group having recurrent respiratory problems as compared to the other group. According to a report by Global Initiative For Asthma (GINA 2018) $\mathrm{FEV}_{1}$ and $\mathrm{FEV}_{1} / \mathrm{FVC}$ are markers of expiratory airflow obstruction ${ }^{29}$. In a study conducted on 72 children with bronchiolitis obliterans, it was found that the baseline spirometric parameters were all below the reference parameters for all variables ${ }^{30}$. In our study since the FVC was also below $80 \%$, it leads us to think that there was some degree of restrictive pathology involved. However, decreased FVC can be seen not only in restrictive disease but can also occur in severe obstructive disease and in case of suboptimal performance while undergoing the procedure in children ${ }^{4,31}$.
PEF is a measure of patency of larger intrathoracic airways. PEF in both the groups was below the standard normal value of $80 \%$ and it was statistically lower in the group with recurrent RP. However, PEF is said to be subjective and effort-dependent and might not reflect the true degree of obstruction in children. $\mathrm{FEF}_{25-75}$ on the other hand represents the mean forced expiratory flow between $25 \%$ to $75 \%$ of the forced vital capacity. It is considered as a marker of small airway patency and is less effort-dependent so it has useful value in the assessment of expiratory obstruction in children. In this study, the value of $\mathrm{FEF}_{25-75}$ was significantly lower in the group with recurrent respiratory problems which indicates that there was the involvement of smaller airways leading to respiratory problems. This shows that children in the recurrent RP group had varying degrees of obstruction in the larger as well as smaller airways.

Bronchodilator reversibility testing in both the groups showed that there was significantly higher reversibility in $\mathrm{FEV}_{1}, \mathrm{FVC}$ and $\mathrm{FEF}_{25-75}$ after nebulization with salbutamol in the recurrent RP group as compared to the other group while there was no difference in $\mathrm{FEV}_{1} / \mathrm{FVC}$. Generally, bronchodilator reversibility is said to be present and suggestive of a reversible obstructive defect when there is a post-bronchodilator increase in $\mathrm{FEV}_{1}$ by $>12 \%$ in children (or $>200 \mathrm{ml}$ in adults) and $>15-25 \%$ increment in $\mathrm{FEF}_{25-72}$. However several studies have found that a cutoff of FEV1 $>12 \%$ correlates poorly with reversibility in children and a lower cutoff would increase the sensitivity of diagnosing asthma in children ${ }^{32,33}$. In a study on post-infectious bronchiolitis obliterans in children and adolescents, it was found that the mean values of $\mathrm{FEV}_{1}$, $\mathrm{FVC}, \mathrm{FEV}_{1} / \mathrm{FVC}$ and $\mathrm{FEF}_{25-75}$ before nebulization with a bronchodilator were all below normal z-score value; there was some improvement post-nebulization but this change was not significant enough to reach normal levels $s^{30}$. Another study has shown that bronchodilator reversibility is seen in healthy children as well as those having obstructive lung disease but the reversibility is greater in asthmatics as compared to healthy children ${ }^{34}$. This finding was seen in our study also where there was 
an improvement in all parameters after nebulization with bronchodilator in both the groups; however the degree of improvement was more in the recurrent RP group as compared to the normal group. In a study comparing the bronchodilator reversibility in healthy children against those with doctor-diagnosed asthma, cystic fibrosis, neonatal chronic lung disease, and current wheezers it was found that the reversibility was comparable between healthy and cystic fibrosis patients while those with neonatal chronic lung disease had higher reversibility as compared to healthy children. Those children who were current wheezers or had doctor-diagnosed asthma had a similar or slightly smaller reversibility than healthy controls. This was explained by the fact that these children were on inhaled corticosteroids which could have led to a decrease in reversibility nearing that of control subjects ${ }^{35}$. Other studies have found that $\mathrm{FEF}_{25-75}$ is a better marker to assess bronchodilator reversibility than $\mathrm{FEV}_{1}{ }^{36-38}$. In our study, although the median value of $\mathrm{FEF}_{25-75}$ reversibility seems higher on gross comparison to $\mathrm{FEV}_{1}$, a detailed comparison between the two was beyond the scope of this study.

The strength of our study is that this is the first study of its kind conducted on children in the context of Nepal. Limitations of our study are: a) Small sample size limited to a tertiary-level teaching medical college because of which the results cannot be extrapolated on a larger population, b) Most of the cases in the recurrent

\section{REFERENCES}

1. Owayed AF, Campbell DM, Wang EEL. Underlying causes of recurrent pneumonia in children. Arch PediatrAdolesc Med. 2000 Feb;154(2):190-4. [PubMed Full Text]

2. Bozdoğan G, Reisli I, Doğu F, Ikincioğullari A, Babacan E. Evaluation of the children with recurrent respiratory infections. J Med Sci.2003 Sep-Dec; 3(56):411-7. [Full Text]

3. Griffiths AG. Chronic or recurrent respiratory symptoms. In: Kleigman RM, St Geme JW III, Blum NJ, Shah SS, Tasker RC, Wilson KM, eds. Nelson Textbook of Pediatrics. $21^{\text {st }}$ ed. Philadelphia: Elsevier; 2020. p. 2161-5.

4. KR Jat et al. Spirometry in children: a clinical review. Prim Care Respir J. 2013 May; 22(2):221-9. [PubMed]

5. Lum S, Bountziouka V, Sonnappa S, Wade A, Cole TJ, Harding $S$, et al. Lung function in children in relation to ethnicity,physique and socioeconomic factors. EurResp J. 2015 Oct; 46:1662-71.[PubMed] respiratory problem were cases of bronchial asthma; a greater mix of other pulmonary diseases might have produced a different result.

\section{CONCLUSION}

From our study, we conclude that children with recurrent respiratory problems tend to have features of obstruction involving the larger intrathoracic airways as well as the smaller airways. The baseline lung function parameters, as well as the percentage of predicted values, are lower than the standard predicted values and postbronchodilator reversibility is higher in the children with recurrent RP as compared to healthy controls. Hence, spirometric study is recommended in all children who present with a history of recurrent respiratory problems so that the type of abnormalities can be identified and treated optimally in time before significant compromise in lung function occurs.

\section{ACKNOWLEDGEMENT}

We would like to extend our heartfelt gratitude to Mrs. Bibila Poudel (breath educator) who helped us in conducting the spirometry. We are also grateful to the participants for their willingness in being a part of this study.

Conflict of interest: None Source(s) of support: None

6. Langkulsen U, Jinsart W, Karita K, Yano E. Respiratory symptoms and lung function in Bangkok school children. European J Public Health. 2006 May; 16(6):676-81. [PubMed]

7. Quanjer PH, Stanojevic S, Cole TJ, Baur X, Hall GL, Culver $\mathrm{BH}$, et al. Multi-ethnic reference values for spirometry for the 3-95 $\mathrm{yr}$ age range: the global lung function 2012 equations. EurRespir J. 2012 Jun; 40:1324-43.[PubMed].

8. Lum S, Bountziouka V, Quanjer P, Sonnappa S, Wade A, Beardsmore $C$, et al.Challenges in collating spirometry reference data for South-Asian children: an observational study. PLoS ONE.2016 Apr; 11(4): e0154336.[Full Text]

9. Fran囚a DC, Camargos PA, Jones MH, Martins JA, Vieira BP, Colosimo EA, et al. Prediction equations for spirometry in four- to six-year old children. J Pediatr (Rio J). 2016 Jul-Aug;92:400-8.[PubMed| Full Text]

10. Stanojevic S, Wade A, Stocks J, Hankinson J, Coates $A L$, Pan $H$, et al. Reference ranges for spirometry 
across all ages- A new approach. Am J RespirCrit Care Med. 2008; 177:253-60. [PubMed]

11. Singh V, Kurrey VK, Khandwal O, Phuljhele S. Evaluation of lung function by spirometry in 12-14 yrs adolescents in schools of Raipur city Chhattisgargh. Inter J Medical Sci Res Prac.2014; 1(1):16-8. [Abstract]

12. Constant C, Sampaio I, Negreiro F, Aguiar P, Silva $A M$, Salgueiro $M$, et al. Respiratory disease screening in school-aged children using portable spirometry. J Pediatr (Rio J). 2011; 87(2):123-30.[PubMed| Full Text]

13. Sylvester KP, Patey RA, Milligan P, Dick M, Rafferty $\mathrm{GF}$, Rees $\mathrm{D}$, et al. Pulmonary function abnormalities in children with sickle cell disease. Thorax. 2003 Dec;59:67-70. [PubMed]

14. Marostica PJ, Weist AD, Eigen $H$, et al. Spirometry in 3- to 6-year-old children with cystic fibrosis. Am J RespirCrit Care Med.2002 Jul;166(1):67-71. [PubMed| Full text]

15. Brumback LC, Davis SD, Kerby GS, Kloster M, Johnson $R$, Castile $R$, et al. Lung function from infancy to preschool in a cohort of children with cystic fibrosis. European Respiartory Journal.2013;41(1):60-6. [Full Text]

16. Kaslovsky R, Sadof M. Spirometry for the primary care pediatrician. Pediatrics in review. 2014 Nov; 35:465.[PubMed| Full Text]

17. Adekile AD, Azab AF, Owayed A, Khadadah M. Correlates of pulmonary function in children with sickle cell disease and elevated fetal hemoglobin. Med PrincPract. 2018; 27:49-54.[Full Text]

18. Patria MF, Longhi B, Lelii M, Tagliabue C, Lavelli M, Galeone $C$, et al. Children with recurrent pneumonia and non-cystic fibrosis bronchiectasis. Italian J Pediatrics. 2016; 42:13.[PubMed| Full Text]

19. Dombkowski KJ, Hassan F, Wasilevich EA, Clark SJ. Spirometry use among pediatric primary care physicians. Pediatrics. 2010 Oct;126(4):682-87. [PubMed]

20. Ayuk AC, Uwaezuoke SN, Ndukwu Cl, Ndu IK, Iloh KK, Okoli CV. Spirometry in asthma care: A review of the trends and challenges in pediatric practice. Clinical medicine insights: Pediatrics. 2017; 11:1-6.[PMC]

21. Debley J, Filbrun AG, Subbarao P. Clinical applications of pediatric pulmonary function testing: Lung function in recurrent wheezing and asthma. Pediatric allergy, immunology and pulmonology. 2011 Jun; 24(2):69-76. [Full Text]

22. Ferris BG. Epidemiology Standardization Project (American Thoracic Society). Am Rev Respir Dis. 1978; 118(6 Pt 2):1-120. PMID:742764. [PubMed]
23. Brouwer AFJ, Visser CAN, Duiverman EJ, Roorda RJ, Brand PLP. Is home spirometry useful in diagnosing asthma in children with nonspecific respiratory symptoms? PediatrPulmonol. 2010 Mar; 45:326-32. [PubMed]

24. Miller MR, Hankinson J, Brusasco V, Burgos F, Casaburi R, Coates A, et al. Standardisation of spirometry. EurRespir J. 2005;26:319-38. [PubMed| Full Text]

25. Murray $C$, Foden $P$, Lowe $L$, Durrington $H$, Custovic A, simpson A. Diagnosis of asthma in symptomatic children based on measures of lung function: an analysis of data from a population-based birth cohort study. Lancet Child Adolesc Health. 2017 Oct; 1(2):114-23.[PubMed| Full Text]

26. Moeller A, Carlsen KH, Sly PD, Baraldi E, Piacentini G, Pavord I, et al. Monitoring asthma in childhood: lung function, bronchial responsiveness and inflammation. EurResp Rev. 2015; 24:204-15. [PubMed]

27. Colom AJ, Maffey A, Bournissen FG, Teper A. Pulmonary function of a paediatric cohort of patients with postinfectious bronchiolitis obliterans. A long-term follow up. Thorax. 2014 Nov;70:169-74. [PubMed]

28. Kim J, Kim M-J, Sol IS, Sohn MH, Yoon H, Shin HJ, et al. Quantitative CT and pulmonary function in children with postinfectious bronchiolitis obliterans. PLoS ONE. 2019 Apr; 14(4):e0214647.[PubMed]

29. Global initiative for asthma. Global strategy for asthma management and prevention, 2018. Available from: www.ginasthma.org.

30. Mattiello R, Vidal PC, Sarria EE, Pitrz PM, Stein RT,Mocelin HT, et al. Evaluating bronchodilator response in pediatric patients with post-infectious bronchiolitis obliterans: use of different criteria for identifying airway reversibility. J Bras Pneumol. 2016 May-Jun; 42(3): 174-8.[PubMed]

31. Levy ML, Quanjer PH, Booker R, Cooper BG, Holmes $\mathrm{S}$, Small I, et al. Diagnostic spirometry in primary care : Proposed standards for general practice compliant with American Thoracic Society and European Respiratory Society recommendations : a General Practice Airways Group (GPIAG) 1 document, in association with the Association for Respiratory Technology \& Physiology (ARTP) 2 and Education for Health. Prim Care Respir J. 2009; 18(3):130-47. [PubMed]

32. Tse SM, Gold DR, Sordillo JE, Hoffman EB, Gillman MW, Rifas-Shiman SL, et al. Diagnostic accuracy of the bronchodilator response in children. J Allergy Clinlmmunol. 2013 May;132(3):554-9.e5. [Full Text] 
33. Kang $\mathbf{X H}$, Wang $\mathbf{W}$, Cao L. A clinical study to determine the threshold of bronchodilator response for diagnosing asthma in Chinese children. World Journal of Pediatrics. 2019 Aug; 15:559-64.[PubMed]

34. Nielsen KG, Bisgaard H. Discriminative capacity of bronchodilator response measured with three different lung function techniques in asthmatic and healthy children aged 2 to 5 years. Am J RespirCrit Care Med. 2001; 164:554-9. [PubMed| Full Text]

35. Thamrin C, Gangell CL, Udomittipong K, Kusel MM, Patterson $\mathrm{H}$, Fukushima $\mathrm{T}$, et al. Assessment of bronchodilator responsiveness in preschool children using forced oscillations. Thorax. 2007 Sep; 62:814-9.[PubMed]
36. Simon MR, Chinchilli VM, Phillips BR, Sorkness CA, Lemanske RF, Szefler SJ, et al. $\mathrm{FEF}_{25-75}$ and $\mathrm{FEV}_{1} / \mathrm{FVC}$ in relation to clinical and physiologic parameters in asthmatic children with normal $\mathrm{FEV}_{1}$ values. J Allergy Clinlmmunol. 2010 Sep; 126(3):527-34.e8.[PubMed]

37. Vilozni D, Hakim F, Livnat G, Ofek M, Bar-Yoseph R, Bentur L. Assessment of airway bronchodilation by spirometry compared to airway obstruction in young children with asthma. Can Respir J. 2016; article ID5394876.[PubMed| Full Text]

38. Rao DR, Gaffin JM, Baxi SN, Sheehan WJ, Hoffman EB, Phipatanakul W. The utility of forced expiratory flow between $25 \%$ and $75 \%$ of vital capacity in predicting childhood asthma morbidity and severity. J Asthma. 2012 Aug; 49(6):586-93.[PubMed] 